\title{
Accessibility levels to potable Water Supply in Rural Areas of Akwa Ibom State, Nigeria 1Akpan P. A. and ${ }^{2}$ Atser Jacob
}

\begin{abstract}
The UN in the year 2000 enlisted improved access to potable water supply as one of the development goals to be achieved by 2015 in developing countries including Nigeria. This study therefore, examined the levels of access to potable water supply in rural areas of Akwa Ibom State against the background of meeting the Millennium Development Goals (MDGs) in 2015. to carry out the investigation, the map of the study area was divided into 500 grid squares (quadrates) and a total of 50 rural communities were sampled using table of random numbers. Community heads or their spokesmen/women in the sampled areas were target respondents and data on major sources of water supply, distance to the nearest major source of water supply and the number of water boreholes in the communities were collected and analyzed. The population of the communities provided a basis for evolving an index that measured the levels of access to potable water supply in the study area. The use of GIS was subsequently employed to map out the study area on the basis of levels of access to potable water supply. The overall result depicts a very poor status scenario as majority of the communities studied have deteriorating conditions. The study recommends among others that a state of emergency be declared in the water sector, if the MDGs are to be achieved in the water sector by 2015.
\end{abstract}

Key words: Rural, Water Supply, Akwa Ibom, Nigeria

\section{Introduction}

kwa Ibom State is one of the
states in the Niger Delta Region of Nigeria. Generally, the region is characterized by rising waves of restiveness due to low levels of development in the face of increasing oil exploration and exploitation activities. The State is a major oil producing state and thus, contributes significantly to the total revenue base of the nation. Above all, Akwa Ibom State is the second most densely populated state in the Niger Delta, with average density as high as 634 persons per kilometer square (NPC 2007). Interestingly, about 87.9 percent of the population in the state is rural (NPC 2007). Ajala et al (2005) and Olayiwola(2005), asserted that one of the major factors responsible for low level of rural development is the imbalance in social infrastructure distribution. Recently, social infrastructure development was one of the cardinal issues raised during the convention in 2000 , of 147 heads of state and government involving 187 countries, including Nigeria, to fashion out ways of achieving realistic development through a comprehensive and coordinated strategy that would address simultaneously the special needs of the world's poorest countries (UN2000, UN2001, World Bank 2002). The outcome of the meeting was the declaration of the millennium Development Goals (MDGs) which have indicators ranging from halving extreme poverty, increasing access to safe drinking water, halting the spread of preventable diseases to providing access to basic education, all by the year 2015. If it is considered that half of the target period for achieving the MDGs is spent, then it is expedient to analyze the levels of access to water supply as a component of social infrastructure in the rural areas where the majority of the population is found. This is because improved access to water supply is customary or at least widely encouraged and approved in both developed and developing world. A study of this nature would showcase the trend of development in the water sector and thus, reveal the extent of government commitment towards meeting the Millennium Development Goals. It is therefore content to investigate the levels of access to water supply in the rural communities of a State that contributes significantly to the revenue base of Nigeria.

\section{The study area}

Akwa Ibom State is the study area. It is one of the oil rich states in the Niger Delta Region of Nigeria. Located in the southeastern coast of Nigeria, Akwa Ibom State was created on September 23, 1987 from the former Cross River State of Nigeria. The State is wedged in between Rivers, Abia and Cross river States and the Republic of Cameroon to the Southwest, North, East and Southeast respectively while the Bight of Bonny bordered the State to the South. It lies between

${ }^{1}$ Department of Geography/Regional Planning, University of Uyo;

2Department of Urban \& Regional Planning, University of Uyo ,Nigeria. jacobatser@yahoo.com 
latitudes $4^{\circ} 32^{\prime}$ and $5^{\circ} 32^{\prime}$ North of the Equator, and longitudes $7^{\circ} 28^{\prime}$ and $8^{\circ} 25^{\prime}$ East of the Greenwich Meridian. According to NPC (1998), Akwa Ibom State has a total land area of $6,187 \mathrm{~km}^{2}$, which represents $0.67 \%$ of the total land mass of Nigeria. The State has 31 Local Government Areas with Uyo, Eket, Ikot Ekpene, Abak, Etinan, Ikot Abasi and Oron being the most developed urban centres. According to the 2006 National Population Census result, Akwa Ibom State had a total population of 3920208 persons out of which $87.89 \%$ constituted rural population while 12.11percent formed the urban population (NPC2007), thereby accounted for $2.7 \%$ of the over all national population. The most striking characteristic of the population of Akwa Ibom State is its crude density. When compared with other states in the south-south and southeast, the region is one of most densely settled state. In fact, apart from Imo and Anambra States, Akwa Ibom State is the most densely populated state with densities as high as 634 persons per square kilometer in Nigeria (NPC2007). The state is virtually surrounded by water with Atlantic Ocean flanking the southern part, Cross River to the east and Imo River to the west. As a coastal state, it is characterized by many streams and creeks. This scenario has created an illusion of abundance of water for domestic uses and thus, eclipsed the reality that adequate water is an increasingly scarce commodity in the region. Investigation has shown that streams which are the major sources of domestic water supply in rural areas are drying up (Abasiodiong 2003). In the urban areas the ugly situation has led to desperate resort to indiscriminate underground water extraction through borehole drilling. The implications of this development are obvious. Beside characteristically long queues of water boreholes, water supply from most boreholes is not safe due to contaminants loading in them as a result of non-treatment. Thus, the increasing waves of water borne diseases in our society are due to consumption of water from untreated sources (Bassey 2003).

\section{Method of study}

This study employs exploratory and descriptive approaches to investigate the nature and scale of the problem using survey research design. Data were collected on 4 indicator variables of water supply accessibility parameters. To achieve this, map of Akwa
Ibom State drawn on a scale of $1 \mathrm{~cm}$ represents $2.5 \mathrm{~km}$ was divided into grid squares (quadrates) of $0.5 \mathrm{~cm}$ sq to provide a framework for selection of units of observations. The use of grid squares is not new as Abiodun (1981) applied grid squares as units of observations to analyze industrial growth patterns in Nigeria between 1962 and 1974 and had valid conclusions. A total of 500 quadrates were subsequently numbered serially and sampled using table of random numbers. A total of 50 rural communities were sampled. This represents $10 \%$ sampling fraction. Udofia (2006) recommends a sampling fraction of $10 \%$ for generalization of research findings. In each sampled community, community heads or their spoke men/women were contacted as target respondents on the premises that their opinions represent those of the community. A total of 28 local government areas were covered in this investigation. Data on population of community, number of water boreholes in each community, major source of water supply in the community and distance to major source of water supply were obtained. An index was subsequently evolved measure the levels of access to water supply in each community taken cognizance of existing national standards for achieving adequate water supply in rural areas. The use of GIS (Geographic Information System) was employed to map the study area on the basis of levels of accessibility to water supply. Access to Water Supply

Field investigation as revealed in Table 1 shows indicator variables for levels of access to water supply. These indicator variables are population, number of boreholes, distance to nearest water borehole and major source of community water supply. According to the field data in Table 1, only 11 communities (22\%) relied exclusively on water borehole as the major source of domestic water supply. A total of 39 communities (78\%) depended largely on sources that are not sustainable such as rivers, streams, wells and ponds. Water is so easily contaminated at the slightest chance and as such, over-dependence on sources that do not guarantee healthy living is worrisome. In terms of number of water boreholes, the study area had a total of 125 water boreholes spatially distributed among the 50 sampled rural communities. While a total of 9 communities (18\%) had 5 water boreholes and above, 29 communities (58\%) recorded less 
than 5 boreholes each. Poorest conditions were observed in 12 communities (24\%), which had no water borehole at all. The maximum permissible distance to major source of water supply was employed to measure accessibility level of each community. Table 1 also shows that only 18 communities $(36 \%)$ did not exceed the maximum permissible distance of 30 minutes $(0.5 \mathrm{hr})$ for accessing water supply points (FGN 2000, FGN 1991). An overall index which defines the levels of access to water supply was computed from the summation of the three indicator variables as shown in Table1. An index of one (1) indicates attainment of minimum desirable level while values above one indicate improved performance. Values below one show the tendency towards poorer conditions. A total of 32 communities (64\%) have low positive values, which depict low performance levels (Fig.1). Negative index values signifying adverse conditions were observed among 18 communities, which represent 36 percent. This result agrees with Amina (2005) that about 72 million Nigerians have no access to safe water supply. Similarly, CBN's (1999) finding that, 82 percent of rural population in Nigeria has no access to safe drinking water is recaptured by this result.

\section{Conclusion}

In conclusion therefore, the presentation and analysis of data on levels of access to water supply in the study area is indicative that the study area has very poor access to potable water supply. This is because no community has attained the minimum recommended standard of one borehole for every 250 population. In all the 50 sampled communities, the number of boreholes does not correlate positively with the existing population. Consequently unsustainable sources of domestic water supply such as rivers and streams are still predominant in the study area. This is a worrisome development trend considering the fact that half of the target period (2015) for achieving universal access to water supply as one of the indicators of Millennium Development Goals (MDGs) is already spent. Although, there is a general picture of poor access to water supply in the study area, highly deteriorating conditions are observed in 18 communities thereby portraying some levels of inequality among the communities in terms of access to potable water supply.
On the basis of the deteriorating levels of access to potable water supply in rural areas of Akwa Ibom State, there is need to declare a state of emergency in the water sector considering the fact that half of the target period for achieving the MDGs is already spent. By way of remedial measures, the state and the Local Government Areas should put in place deliberate efforts to encourage the participation of the Local communities in development projects that have direct bearing on welfare of the rural populace. The local communities should be involved right from the needs assessments stage, priority need identification, project implementation as well as monitoring and evaluation. By this measure, the local communities will have a sense of ownership in government projects, as they will see such projects as theirs, thereby doing everything possible to ensure their sustainability. In the wake of the current drive of the federal government towards liberalization and privatization, there is an urgent need for the involvement of the private sector in the development of water supply projects in the rural areas. For instance, the private sector can invest substantial capital to harness the rich aquifer resources in the state and develop water boreholes for commercial use. Above all, it may be necessary to review the Land Use Act of 1978 in order to allow private investors have easy access to land for development purposes. This is because the existing land tenure system appears to be rigid. There is also need to encourage self-help efforts of individuals, various voluntary organizations, community based organization etc in Akwa Ibom State. Such encouragement could take the form of appreciation by the State and local governments of those whose activities have impacted on the general welfare of the rural populace. Honoring such people or groups will ginger them to do more while encouraging others to emulate them. Other development agencies such as Niger Delta Development Commission (NDDC), African Development Bank (ADB), and United Nations Development Programmes (UNDP) should intensify their efforts while government should harness such opportunities offered by these agencies, to speed up rural development. The NDDC in particular should be more focused on issues of welfare while its administrative machinery should be decentralized with offices established in each 
local government area in the region for effective monitoring and coordination of existing projects. Besides, such offices should be charged with the responsibility of conducting needs assessment in consultation with the rural populace, for project intervention as well as provide data bank on

\section{References}

Abasiodiong, M. (2003), Water security, supply and management problems in Akwa Ibom State. Paper presented at the 2003 World Environment Day Round Table in Uyo, AKS.

Abiodun, J.O. (1981), Aspects of the Spatial Impact of Development Efforts: A Case Study of Nigeria. TESG, 72 (2), 274-279.

Ajala, O., Sanni, L. and Adeyinka, S. (2005), Accessibility to Health Care Facilities: A panacea of sustainable rural development in Osun State, Southwestern Nigeria. Journal of Human Ecology, 18 (2), 121-128.

Amina, J.I. (2005). MDGs and the City: Nigeria Experience. Paper Presented at the Common Wealth Association of Planner's Workshop, Abuja, Nigeria

Bassey, S.A. (2003), The Politics of safe water delivery in Nigeria. Paper presented at the 2003 World Environment Day Round Table in Uyo, AKS, Nigeria.

Central Bank of Nigeria (1999), Nigeria's Development Prospects Poverty Assessment and Alleviation Study. CBN/Word Bank, Abuja.

Federal Government of Nigeria (2000), National Water Supply and Sanitation Policy.

Federal Ministry of Water, Resources, Department of Water Supply and Quality Control, First Edition. Abuja, Nigeria. Federal Government of Nigeria (1991), Nigeria's Health Profile. Federal Ministry of social needs of each community in the local government area. Such an assessment should aim at gathering information in an encyclopedic form to serve as a veritable document for every planning and development agency in the state; at present, such an essential compendium is lacking.

\section{Health and Social Services (FMOH and SS)}

Lagos, Nigeria.

National Population Census (NPC) 1998. 1991

National Population Census of the Federal

Republic of Nigeria: Analytical Report at the

National Level. NPC, Abuja, $p 8$.

National Population Census (NPC) 2007. 2006

National Population Census Result: Legal

Notice on the Details of the Breakdown of the

National and State Provisional Totals. Printed and published by the Federal Government

Printer, Lagos, Nigeria.

FGP71/52007/2500(OL24)

Olayiwola, L.M. and Adeleye, A. (2005), Rural infrastructure development in Nigeria between 1960 and 1990: Problems and challenges. Journal of Social Science, 11 (2), 91-96.

Udofia, E.P. (2006), Fundamentals of Social Science Statistics. Enugu: Immaculate Pubs. Ltd.

United Nations (2000), Millennium

Development Goals (MDGs).

http//www:sovereignty.net/p/gov/mad e.html

United Nations (2001), Indicators of Sustainable Development: Guidelines and Methodologies.

United Nations, New York.

World Bank (2002), Reaching the Rural PoorA Renewed Strategy for Rural Development. The World Bank, Washington DC. 
Table 1 Levels of access to water supply in the study area

\begin{tabular}{|c|c|c|c|c|c|c|c|c|c|c|c|}
\hline \multirow[t]{2}{*}{ Communities } & \multicolumn{4}{|c|}{ Borehole } & \multicolumn{3}{|c|}{ Distance } & \multicolumn{3}{|c|}{ Major sources } & \multirow[t]{2}{*}{ Index } \\
\hline & $\mathbf{O}$ & $\mathbf{E}$ & D & $\mathbf{L}_{1}$ & $\mathbf{o}$ & d & $\mathbf{L}_{2}$ & $\mathbf{O}$ & $\mathbf{E}$ & $\mathbf{L}_{3}$ & \\
\hline 1 Ikot Abia & 1 & 8.76 & -7.76 & 0.11 & 1.5 & -1.0 & -1.0 & 1 & 3 & 0.33 & -0.19 \\
\hline 2 Ikot Ekpaw & 2 & 12.76 & -10.76 & 0.16 & 1.0 & -0.5 & 0.0 & 1 & 3 & 0.33 & 0.16 \\
\hline 3 Ikot Obio Odongo & 3 & 11.75 & -8.75 & 0.26 & 0.5 & 0.0 & 1.0 & 1 & 3 & 0.33 & 0.53 \\
\hline 4 Ndukpoise & 0 & 20.39 & -20.39 & 0 & 1.5 & -1.0 & -1.0 & 1 & 3 & 0.33 & -0.22 \\
\hline 5 Iqua & 0 & 9.16 & -9.16 & 0 & 1.5 & -1.0 & -1.0 & 1 & 3 & 0.33 & -0.22 \\
\hline $6 \quad$ Nkari & 2 & 18.72 & -16.72 & 0.11 & 1.0 & -0.5 & 0 & 1 & 3 & 0.33 & 0.15 \\
\hline 7 Nwot Ikono & 2 & 7.78 & -5.78 & 0.26 & 1.5 & -1.0 & -1.0 & 1 & 3 & 0.33 & -0.14 \\
\hline 8 Mbokpu Eyekan & 2 & 13.9 & -11.9 & 0.14 & 1.0 & -0.5 & 0 & 1 & 3 & 0.33 & 0.16 \\
\hline 9 Ukana & 4 & 7.48 & -3.48 & 0.40 & 0.5 & 0 & 1.0 & 3 & 3 & 1.0 & 0.80 \\
\hline 10 Mbiabong Ikon & 0 & 6.02 & -6.02 & 0 & 2.0 & -1.5 & -2.0 & 1 & 3 & 0.33 & -0.56 \\
\hline 11 Ikot Udo Offong & 0 & 10.13 & -10.13 & 0 & 2.0 & -1.5 & -2.0 & 1 & 3 & 0.33 & -0.56 \\
\hline 12 Utu Edem Usung & 5 & 16.82 & -11.82 & 0.30 & 0.5 & 0 & 1.0 & 3 & 3 & 1.0 & 0.77 \\
\hline 13 Etibe Afaha & 0 & 49.06 & -49.06 & 0 & 2.0 & -1.5 & -2.0 & 1 & 3 & 0.33 & -0.78 \\
\hline 14 Ikot Uko & 1 & 3.19 & -2.19 & 0.31 & 0.5 & 0 & 1.0 & 1 & 3 & 0.33 & 0.55 \\
\hline 15 Ukpom Usung Ubom & 2 & 3.57 & -1.57 & 0.56 & 0.5 & 0 & 1.0 & 1 & 3 & 0.33 & 0.63 \\
\hline 16 Ikot Udo Obobo & 0 & 12.85 & -12.85 & 0 & 2.0 & -1.5 & -2.0 & 1 & 3 & 0.33 & -0.78 \\
\hline 17 Use Offot & 15 & 21.63 & -6.63 & 0.70 & 0.5 & 0 & 1.0 & 3 & 3 & 1.0 & 0.90 \\
\hline 18 Mbiaso & 2 & 3.17 & -1.17 & 0.63 & 0.5 & 0 & 1.0 & 1 & 3 & 0.33 & 0.65 \\
\hline 19 Okobo Ebughu & 3 & 17.39 & -14.39 & 0.17 & 0.5 & 0 & 1.0 & 1 & 3 & 0.33 & 0.50 \\
\hline 20 Ndom Ebom & 5 & 42.33 & -37.33 & 0.12 & 1.0 & -0.5 & 0 & 1 & 3 & 0.33 & 0.15 \\
\hline 21 Ikot Etefia & 0 & 41.45 & -41.45 & 0 & 2.0 & -1.5 & -2.0 & 1 & 3 & 0.33 & -0.78 \\
\hline 22 Ikot Ubo & 4 & 27.94 & -23.94 & 0.14 & 0.5 & 0.0 & 1.0 & 1 & 3 & 0.33 & 0.49 \\
\hline 23 Mbak Ikot Abasi & 4 & 11.09 & -7.09 & 0.36 & 1.0 & -0.5 & 0 & 3 & 3 & 1.0 & 0.45 \\
\hline 24 Ito Ika & 0 & 4.25 & -4.25 & 0 & 2.0 & -1.5 & -2.0 & 1 & 3 & 0.33 & -0.78 \\
\hline 25 Urukim & 1 & 14.50 & -13.50 & 0.35 & 1.5 & -1.0 & -1.0 & 1 & 3 & 0.33 & -0.11 \\
\hline 26 Ikot Akpabim & 4 & 8.45 & -4.45 & 0.47 & 0.5 & 0 & 1.0 & 1 & 3 & 0.33 & 0.60 \\
\hline 27 Mkpok & 6 & 15.40 & -9.40 & 0.38 & 0.5 & 0 & 1.0 & 3 & 3 & 1.0 & 0.79 \\
\hline 28 Ikot Odube & 2 & 2.27 & -0.27 & 0.88 & 1.0 & -0.5 & 0 & 1 & 3 & 0.33 & 0.40 \\
\hline 29 Ituk Mbang & 5 & 28.20 & -23.20 & 0.18 & 1.0 & -0.5 & 0 & 3 & 3 & 1.0 & 0.39 \\
\hline 30 Nsasak & 4 & 12.94 & -8.94 & 0.31 & 1.0 & -0.5 & 0 & 1 & 3 & 0.33 & 0.21 \\
\hline 31 Ikot Uniang & 0 & 10.58 & -10.58 & 0 & 2.0 & -1.5 & -2.0 & 1 & 3 & 0.33 & -0.78 \\
\hline 32 Abak Ikot & 3 & 6.69 & -3.69 & 0.45 & 0.5 & 0 & 1.0 & 1 & 3 & 0.33 & 0.59 \\
\hline 33 Ekparakwa & 3 & 17.02 & 14.02 & 0.18 & 1.0 & -0.5 & 0 & 1 & 3 & 0.33 & 0.17 \\
\hline 34 Mbiokporo I & 5 & 8.38 & -3.38 & 0.60 & 1.0 & -0.5 & 0 & 1 & 3 & 0.33 & 0.31 \\
\hline 35 Ikot Inyang & 0 & 6.88 & -6.88 & 0 & 2.0 & -1.5 & -2.0 & 1 & 3 & 0.33 & -0.78 \\
\hline 36 Ikot Ukana & 0 & 6.04 & -0.6 .04 & 0 & 2.0 & -1.5 & -2.0 & 1 & 3 & 0.33 & -0.78 \\
\hline 37 Okoro Inyang & 2 & 2.33 & -0.33 & 0.86 & 1.0 & -0.5 & 0 & 3 & 3 & 1.0 & 0.62 \\
\hline 38 Akpa Utong & 3 & 11.21 & -8.21 & 0.27 & 0.5 & 0 & 1.0 & 1 & 3 & 0.33 & 0.53 \\
\hline 39 Ikot Oku Ikono & 6 & 9.82 & -3.82 & 0.61 & 1.0 & -0.5 & 0 & 3 & 3 & 1.0 & 0.54 \\
\hline 40 Eyo Nsek & 1 & 3.36 & -2.36 & 0.30 & 1.5 & -1.0 & -1.0 & 1 & 3 & 0.33 & -0.12 \\
\hline 41 Ikot Ibiok & 5 & 18.64 & -13.64 & 0.27 & 0.5 & 0 & 1.0 & 3 & 3 & 1.0 & 0.76 \\
\hline 42 Atiamkpat & 2 & 18.15 & -16.15 & 0.11 & 0.5 & 0 & 1.0 & 1 & 3 & 0.33 & 0.48 \\
\hline 43 Ibiaku Uruan & 5 & 23.09 & -18.09 & 0.22 & 1.5 & -1.0 & -1.0 & 3 & 3 & 1.0 & 0.07 \\
\hline 44 Utu Nsekhe & 4 & 6.65 & -2.65 & 0.60 & 0.5 & 0 & 1.0 & 3 & 3 & 1.0 & 0.87 \\
\hline 45 Mbiakpa Ibakesi & 1 & 13.97 & -12.97 & 0.07 & 1.5 & -1.0 & -1.0 & 1 & 3 & 0.33 & -0.20 \\
\hline 46 Aka Ekpeme & 3 & 6.70 & -3.70 & 0.45 & 0.5 & 0 & 1.0 & 1 & 3 & 0.33 & 0.59 \\
\hline 47 Nung Udoe Itak & 1 & 20.59 & -19.59 & 0.10 & 1.0 & -0.5 & 0 & 1 & 3 & 0.33 & 0.14 \\
\hline 48 Ikot Akpadem & 1 & 13.18 & -12.18 & 0.08 & 0.5 & 0 & 1.0 & 1 & 3 & 0.33 & 0.47 \\
\hline 49 Ikot Ibok & 0 & 8.83 & -8.83 & 0 & 2.0 & -1.5 & -2.0 & 1 & 3 & 0.33 & -0.78 \\
\hline 50 Ekeya & 1 & 35.54 & -34.54 & 0.03 & 1.5 & -1.0 & -1.0 & 1 & 3 & 0.33 & -0.21 \\
\hline
\end{tabular}

Source: Author's Fieldwork (2006)

Key to Table 1

$0=$ Observed (number of boreholes, distance to major source of supply and source of supply)

$\mathrm{e}=$ expected (one borehole $/ 250$ persons, 30 minutes or $0.5 \mathrm{hr}$ to go, get water from borehole and return home, FGN 2000, FMOH 1991).

$\mathrm{d}=$ deviation $(\mathrm{o}-\mathrm{e}) \quad \mathrm{L}=$ level of achievement $(\mathrm{o} \div \mathrm{e} \mathrm{x} 1) \quad$ Index $=$ Summation of $\mathrm{L}_{1}+\mathrm{L}_{2}+\mathrm{L}_{3} \div 3$

Major sources of water supply \{Borehole (3), well (2) stream/River/Pond (1)\} 


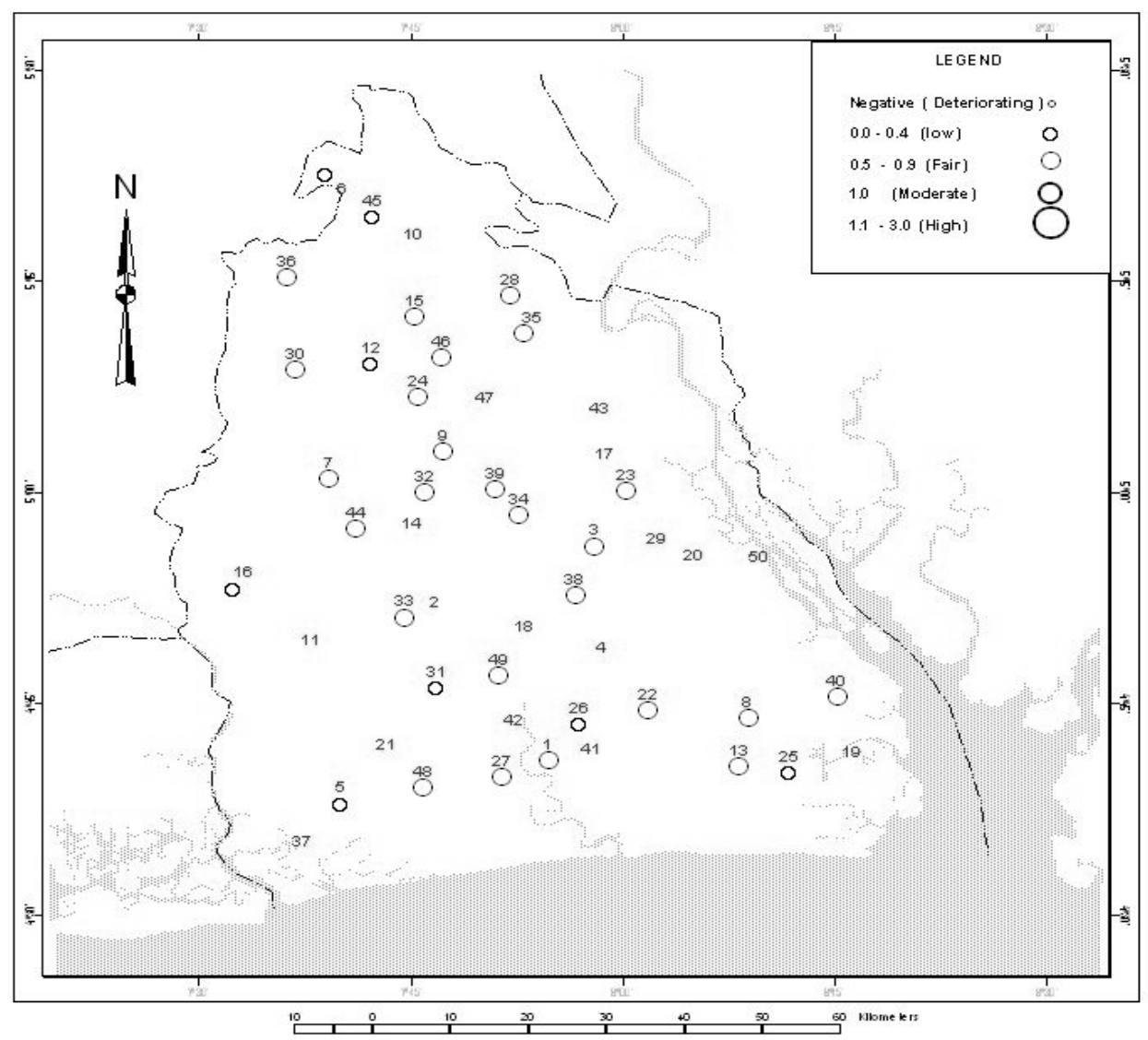

Fig. 4.1: Levels of Access to Water Supply 